\title{
Quality Improvement Guidelines for Central Venous Access
}

\author{
Curtis A. Lewis, MD, Timothy E. Allen, MD, Dana R. Burke, MD, John F. Cardella, MD, Steven J. Citron, MD, \\ Patricia E. Cole, MD, PhD, Alain T. Drooz, MD, Elizabeth A. Drucker, MD, JD, Ziv J. Haskal, MD, \\ Louis G. Martin, MD, A. Van Moore, MD, Calvin D. Neithamer, MD, Steven B. Oglevie, MD, \\ Kenneth S. Rholl, MD, Anne C. Roberts, MD, David Sacks, MD, Orestes Sanchez, MD, Anthony Venbrux, MD, \\ Curtis W. Bakal, MD, MPH, for the Society of Interventional Radiology Standards of Practice Committee
}

J Vasc Interv Radiol 2003; 14:S231-S235

CENTRAL venous access is an integral component in the care of patients with malignant, infectious, and chronic diseases. Image-guided placement of central venous access catheters has been proven to be very safe and effective in providing access to the central venous circulation (1-21). Image-guided percutaneous placement of venous catheters and ports has become the method of choice in many institutions because it has reduced morbidity and mortality and has helped to reduce costs and length of stay in the hospital $(5,7,8,10-$ 13,16-25).

Participation by the radiologist in patient follow-up is an integral part of central venous access and will increase the success rate of the procedure. Close follow-up, with monitoring and management of the central venous access device, is appropriate for the radiologist.

These guidelines are written to be used in quality improvement programs to assess percutaneously placed central venous access devices. The most important processes of care are (a) patient selection, $(b)$ procedure performance, and (c) patient monitoring. The outcome measures or indicators for these processes are indications, success rates, and

This article first appeared in J Vasc Interv Radiol 1997; 8:475-479.

Address correspondence to the SIR, 10201 Lee Hwy, Suite 500, Fairfax, VA 22030.

(C) SIR, 2003

DOI: 10.1097/01.RVI.0000094590.83406.9e complication rates. Outcome measures are assigned threshold levels.

\section{DEFINITIONS}

Image-guided percutaneous central venous access is defined as the placement of a catheter with its tip in the caval atrial region utilizing the assistance of real-time imaging. The most commonly used imaging techniques during placement include fluoroscopy and ultrasonography.

Tunneled catheters are defined as catheters that travel through a subcutaneous tract prior to exiting the body through a small incision in the skin. Implanted ports are similar to tunneled catheters. However, they do not exit the skin, but terminate with a device buried in the subcutaneous tissues. The catheter exit or implanted port site can be located in several different locations but is usually placed over the torso/neck or peripherally. However, other alternative access routes have been described $(3,9,10$, $15,22,26)$.

Successful placement is defined as follows: introduction of a catheter into the venous system with the tip in the desired location and the catheter functions for its intended use (eg, can be used to deliver medications or for dialysis). Functional success is the most important component of this definition.

While practicing physicians should strive to achieve perfect outcomes (eg, $100 \%$ success; $0 \%$ complications), in practice all physicians will fall short of this ideal to a variable extent. Therefore, indicator thresholds may be used to assess the efficacy of ongoing quality improvement programs. For the purpose of these guidelines, a threshold is a specific level of an indicator that should prompt a review. "Procedure thresholds" or "overall thresholds" reference a group of indicators for a procedure (eg, major complications for the placement of central venous access devices). Individual complications may also be associated with complication-specific thresholds. When measures such as indications or success rates fall below a (minimum) threshold, or when complication rates exceed a (maximum) threshold, a review should be performed to determine causes and to implement changes, if necessary. Thresholds may vary from those listed here; for example, patient referral patterns and selection factors may dictate a different threshold value for a particular indicator at a particular institution. Therefore, setting universal thresholds is very difficult and each department is urged to alter the thresholds as needed to higher or lower values, to meet its own quality improvement program needs.

Complications can be stratified on the basis of outcome. Major complications result in admission to a hospital for therapy (for outpatient procedures), an unplanned increase in the level of care, prolonged hospitalization, permanent adverse sequelae, or death.

Minor complications result in no se- 


\section{Table 1 \\ Indications for Central Venous Access \\ Therapeutic Indications \\ Administration of chemotherapy \\ Administration of total parenteral nutrition \\ Administration of blood products \\ Administration of intravenous medications \\ Intravenous fluid administration \\ Performance of plasmapheresis \\ Performance of hemodialysis \\ Diagnostic Indications \\ To establish or confirm a diagnosis \\ To establish a prognosis \\ To monitor response to treatment \\ For repeated blood sampling}

quelae; they may require nominal therapy or a short hospital stay for observation (generally overnight) (Appendix A). The complication rates and thresholds below refer to major complications.

\section{INDICATIONS FOR CENTRAL VENOUS ACCESS}

Indications for central venous access are listed in Table 1. The threshold for these indications is $95 \%$. When fewer than $95 \%$ of procedures are for these indications, the department will review the process of patient selection.

The decision to place a central venous access device should be made after considering the risks and benefits to each patient. Coagulopathy and sepsis may be relative contraindications to immediate implantation of long-term central venous access devices. Appropriate effort should be made to correct or improve a patient's coagulopathy prior to placement of a central venous catheter. Other factors that may also increase complications include venous stenosis, acute thrombosis, and local skin infection at the insertion site. In patients in whom these findings or abnormalities cannot be corrected, the procedure may still be indicated if the risk/benefit ratio is lower than the alternative methods of diagnosis or treatment.

\section{SUCCESS RATES OF CENTRAL VENOUS ACCESS}

Success rates for central venous access are listed in Table 2, along with recommended threshold values.
Table 2

Success Rates

\begin{tabular}{lcc}
\hline & $\begin{array}{c}\text { Reported Rates } \\
(\%)\end{array}$ & $\begin{array}{c}\text { Threshold } \\
(\%)\end{array}$ \\
\hline $\begin{array}{l}\text { Internal jugular approach }(4,22,27-35) \\
\text { Subclavian vein approach }\end{array}$ & 96 & 95 \\
$\quad$ Catheter $(6,8,11,14,16,17,19,22,23,28,31-33,36-44)$ & 95 & 90 \\
$\quad$ Infusion port $(16,18,22,23,45)$ & 95 & 90 \\
Peripherally inserted central catheters (PICC) & 96 & 90 \\
$\quad(1,7,20,22,23,25,46-51)$ & 96 & 90 \\
Peripherally implanted ports & & 90 \\
$\quad(2,5,10,12,13,16,21,23,24,48,52-57)$ & 96 & 90 \\
Translumbar approach $(9,15,26)$ & &
\end{tabular}

Note.-Success rates and thresholds listed are for the adult population and could be expected to be lower in a pediatric population.

Table 3

Complication Rates and Suggested Thresholds for Central Venous Access

\begin{tabular}{lcc}
\hline \multicolumn{1}{c}{$\begin{array}{c}\text { Specific Major Complications } \\
\text { for Image-guided } \\
\text { Central Venous Access }\end{array}$} & $\begin{array}{c}\text { Rate } \\
(\%)\end{array}$ & $\begin{array}{c}\text { Suggested } \\
\text { Threshold } \\
(\%)\end{array}$ \\
\hline $\begin{array}{l}\text { Subclavian and jugular approaches } \\
\text { Pneumothorax }\end{array}$ & $1-2$ & 3 \\
Hemothorax & 1 & 2 \\
Hematoma & 1 & 2 \\
Perforation & $0.5-1$ & 2 \\
Air embolism & 1 & 2 \\
Wound dehiscence & 1 & 2 \\
Procedure-induced sepsis & 1 & 2 \\
Thrombosis* & 4 & 8 \\
Peripheral placement PICC and peripheral ports & & 0 \\
Pneumothorax/hemothorax & 0 & 2 \\
Hematoma & 1 & 8 \\
Wound dehiscence & 1 & 1 \\
Phlebitis* & 4 & 6 \\
Arterial injury & 0.5 & 2 \\
Thrombosis* & 3 & \\
Procedure-induced sepsis & 1 & \\
\hline * The literature is difficult to define, and most complications & are thought not to be \\
major complications. & & \\
\hline
\end{tabular}

\section{COMPLICATIONS OF CENTRAL VENOUS ACCESS}

Complications are defined as early (occurring within 30 days of placement) or late (occurring after 30 days). Early complications can be subdivided into procedurally related, defined as those that occur at the time or within 24 hours of the intervention, and those occurring beyond that period. Complications that occur at the time of the procedure usually consist of injury to the surrounding vital structures or malpositioning of the catheter tip. The incidence of early complications is lower with image-guided techniques when compared to blind or external landmark techniques $(7,27,31,34,38,43)$.

Complications (major and minor) occur in approximately $7 \%$ of patients when image guidance is used $(7,11$, $14,18,20,31,37,39)$. Published complication rates and suggested thresholds are listed in Table 3.

Published rates for individual types of complications are highly dependent on patient selection and are based on series comprising several hundred pa- 
tients, which is a volume larger than most individual practitioners are likely to treat. It is also recognized that a single complication can cause a rate to cross above a complication-specific threshold when the complication occurs in a small volume of patients (eg, early in a quality improvement program). In this situation, the overall procedure threshold is more appropriate for use in a quality improvement program.

The overall procedure threshold for major complications resulting from image-guided central venous access including the subclavian, jugular and peripheral approaches is $3 \%$.

\section{References}

1. Abi-Nader JA. Peripherally inserted central venous catheters in critical care patients. Heart Lung 1993; 22:428-434.

2. Andrews JC, Walker-Andrews SC, Ensminger WD. Long-term central venous access with a peripherally placed subcutaneous infusion port: initial results. Radiology 1990; 176:45-47.

3. Andrews JC. Percutaneous placement of a Hickman catheter with use of an intercostal vein for access. J Vasc Interv Radiol 1994; 5:859-861.

4. Belani KG, Buckley JJ, Gordon JR, Castaneda W. Percutaneous cervical central venous line placement: a comparison of the internal and external jugular routes. Anesth Analg 1980; 59:40-44.

5. Brant-Zawadzki M, Anthony M, Mercer EC. Implantation of P.A.S.Port venous access device in the forearm under fluoroscopic guidance. Am J Roentgenol 1993; 160:1127-1129.

6. Burnett AF, Lossef SV, Barth $\mathrm{KH}$, et al. Insertion of Groshong central venous catheters utilizing fluoroscopic techniques. Gynecol Oncol 1994; 52:69-73.

7. Cardella JF, Fox PS, Lawler JB. Interventional radiologic placement of peripherally inserted central catheters. J Vasc Interv Radiol 1993; 4:653-660.

8. Cockburn JF, Eynon CA, Virji N, Jackson JE. Insertion of Hickman central venous catheters by using angiographic techniques in patients with hematologic disorders. Am J Roentgenol 1992; 159:121-124.

9. Denny DF Jr, Greenwood LH, Morse SS, Lee GK, Baquero J. Inferior vena cava: translumbar catheterization for central venous access. Radiology 1989; 170:1013-1014.

10. Denny DF Jr. The role of the radiologist in long-term central vein access. Radiology 1992; 185:637-638.

11. Hull JE, Hunter CS, Luiken GA. The Groshong catheter: initial experience and early results of imaging-guided placement. Radiology 1992; 185:803-807.

12. Kahn ML, Barboza RB, Kling GA, Heisel JE. Initial experience with percutaneous placement of the P.A.S.Port implantable venous access device. J Vasc Interv Radiol 1992; 3:459-461.

13. Lewis CA, Sheline ME, Zuckerman AM, Short JK, Stallworth MJ, Marcus DE. Experience and clinical follow-up in 273 radiologically placed peripheral central venous access ports. Radiology 1994; 193(P):245.

14. Lund GB, Trerotola SO, Scheel PF Jr, et al. Outcome of tunneled hemodialysis catheters placed by radiologist. Radiology 1996; 198:467-472.

15. Lund GB, Lieberman RP, Haire WD, Martin VA, Kessinger A, Armitage JO. Translumbar inferior vena cava catheters for long-term venous access. Radiology 1990; 174:31-35.

16. Mauro MA, Jaques PF. Radiologic placement of long-term central venous catheters: a review. J Vasc Interv Radiol 1993; 4:127-137.

17. Mauro MA, Jaques PF. Insertion of long-term hemodialysis catheters by interventional radiologists: the trend continues. Radiology 1996; 198:316-317.

18. Morris SL, Jaques PF, Mauro MA. Radiology-assisted placement of implantable subcutaneous infusion ports for long-term venous access. Radiology 1992; 184:149-151.

19. Robertson LJ, Mauro MA, Jaques PF. Radiologic placement of Hickman catheters. Radiology 1989; 170:1007-1009.

20. Cardella JF, Cardella K, Bacci N, Fox PS, Post JH. Cumulative experience with 1,273 peripherally inserted central catheters at a single institution. J Vasc Interv Radiol 1996; 7:5-13.

21. Baudin BC, Lewis CA. Peripherally implanted ports: patient perspectives and relative cost. J Vasc Interv Radiol 1996; 7:144.

22. Alexander HR. Vascular access in the cancer patient. Philadelphia: J.B. Lippincott, 1994

23. Denny DF Jr. Placement and management of long-term central venous access catheters and ports. Am J Roentgenol 1993; 161:385-393.

24. Foley MJ. Venous access devices: low cost convenience. Diagn Imaging 1993; August: 87-94.

25. Markel S, Reynen K. Impact on patient care: 2652 PIC catheter days in the alternative setting. J Intravenous Nursing 1990; 13:347-351.

26. Azizkhan RG, Taylor LA, Jaques PF, Mauro MA, Lacey SR. Percutaneous translumbar and transhepatic inferior vena caval catheters for prolonged vascular access in children. J Pediatr Surg 1992; 27:165-169.

27. Denys BG, Uretsky BF, Reddy PS. U1- trasound-assisted cannulation of the internal jugular vein: a prospective comparison to the external landmarkguided technique. Circulation 1993; 87: 1557-1562.

28. Bambauer R, Inniger KJ, Pirrung R, Dahlem R. Complications and side effects associated with large bore catheters in the subclavian and internal jugular veins. Artif Organs 1994; 4:318-321.

29. Damen J, Bolton D. A prospective analysis of 1400 pulmonary artery catheterizations in patients undergoing cardiac surgery. Acta Anaesthesiol Scand 1986; 30:386-392.

30. Goldfarb G, Lebrec D. Percutaneous cannulation of the internal jugular vein in patients with coagulopathies: an experience based on 1000 attempts. Anesthesiology 1982; 56:321-323.

31. Lameris JS, Post PJM, Zonderland HM, Kappers-Klunne MC, Schutte HE. Percutaneous placement of Hickman catheters: comparison of sonographically guided and blind techniques. Am J Roentgenol 1990; 155:1097-1099.

32. Skolnick ML. The role of sonography in the placement and management of jugular and subclavian central venous catheters. Am J Roentgenol 1994; 163: 291-295.

33. Sznajder IJ, Zveibil FR, Bitterman H, Weiner $\mathrm{P}$, Bursztein S. Central vein catheterization failure and complication rates by three percutaneous approaches. Arch Intern Med 1986; 146: 259-261.

34. Troianas CA, Jobes DR, Ellison N. Ultrasound-guided cannulation of the internal jugular vein: a prospective randomized study. Anesth Analg 1991; 12: 823-826.

35. Tyden H. Cannulation of the internal jugular vein 500 cases. Scand Soc Anaesthesiologists 1982; 26:485-488.

36. Burri C, Ahnefeld FW. The caval catheter. Heidelberg, New York: Springer-Verlag, 1977.

37. Fernando C, Juravsky L, Yedlicka J, Hunter D, Castaneda-Zuniga W, Amplatz K. Subclavian central venous catheter insertion: angiointerventional technique. Semin Intervent Radiol $1991 ; 8: 78-81$

38. Gualtieri E, Deppe SA, Sipperly ME, Thompson DR. Subclavian venous catheterization: greater success rate for less experienced operators using ultrasound guidance. Crit Care Med 1995; 23:692-697.

39. Openshaw KL, Picus D, Darcy MD, Vesely TM, Picus J. Interventional radiologic placement of Hohn central venous catheters: results and complications in 100 consecutive patients. J Vasc Interv Radiol 1994; 5:111-115.

40. Rosen M, Latto P, Ng S. Handbook of 
percutaneous central venous catheterization. 2nd ed. London: Saunders, 1992.

41. Jaques PF, Campbell WE, Dumbleton S, Mauro MA. The first rib as a fluoroscopic marker for subclavian vein access. J Vasc Interv Radiol 1995; 6:619622.

42. Gray RR. Radiologic placement of indwelling central venous lines for dialysis, TPN and chemotherapy. J Vasc Interv Radiol 1991; 6:133-144.

43. Mansfield PF, Hohn DC, Fornage BD, Gregurich MA, Ota DM. Complications and failures of subclavian-vein catheterizations. N Engl J Med 1994; 331:1735-1738.

44. Moosman DA. The anatomy of infraclavicular subclavian vein catheterization and its complications. Surg Gynecol Obstet 1973; 136:71-74.

45. Brothers TE, Von Moll LK, Niederhuber JE, Roberts JA, Ensminger WD. Experience with subcutaneous infusion ports in three hundred patients. Surg Gynecol Obstet 1988; 166:295-301.

46. Cardella JF, Lukens ML, Fox PS. Fibrin sheath entrapment of peripherally inserted central catheters. J Vasc Interv Radiol 1994; 5:439-442.

47. Goodwin M, Carlson I. The peripherally inserted central catheter. J Intravenous Nursing 1993; 16:93-100.

48. Hovsepian DM, Bonn J, Eschelman DJ. Techniques for peripheral insertion of central venous catheters. J Vasc Interv Radiol 1993; 4:795-803.

49. James L, Bledsoe L, Hadaway L. A retrospective look at tip location and complications of peripherally inserted central catheter lines. J Intravenous Nursing 1993; 16:104-109.

50. Merrell SW, Peatross BG, Grossman MD, Sullivan JJ, Harker G. Peripherally inserted central venous catheters low risk alternatives for ongoing venous access. West J Med 1994; 160:25-30.

51. Andrews JC, Marx MV. The upper arm approach for placement of peripherally inserted central catheters for protracted venous access. Am J Roentgenol 1992; 158:427-429.

52. Bagnall-Reeb H. Initial use of a peripherally inserted central venous access port: a review of the literature. JVAN 1991; 1:10-14.

53. Ensminger WD, Walker SC, Knol JA, Andrews JC. Initial clinical evaluation of a new implanted port accessed by catheter over needle systems. J Infus Chemother 1993; 3:200-203.

54. Kahn ML, Barboza RB. Percutaneous placement of the P.A.S.Port venous access device: one year experience (abstr). Radiology 1992; 185(P):278.

55. Laffer U, Bengtsson M, Starkhammar H. The P.A.S.Port-system: a new totally implanted device for long-term central venous access. Basel: Karger, 1991; 58-64. Laffer U, Bachmann-Mettler I, Metzger U, eds. In: Implantable Drug Delivery Systems.

56. Schuman E, Ragsdale J. Peripheral ports are a new option for central venous access. J Am Coll Surg 1995; 180: 456-460.

57. Starkhammar H, Bengtsson M, Gain $\mathrm{TB}$, et al. A new injection portal for brachially inserted central venous catheter: a multicenter study. Med Oncol Tumor Pharmacother 1990; 7:281-285.

58. Sitzmann JV, Townsend TR, Siler MC, Bartlett JG. Septic and technical complications of central venous catheterization. Ann Surg 1985; 202:766-770.

59. Vazquez RM, Brodski EG. Primary and secondary malposition of silicone central venous catheters. Acta Anaesth Scand 1985; 81:22-25.

60. Fink A, Kosefcoff J, Chassin M, Brook RH. Consensus methods: characteristics and guidelines for use. Am J Public Health 1984; 74:979-983.

61. Leape LL, Hilborne LH, Park RE, et al. The appropriateness of use of coronary artery bypass graft surgery in New York State. JAMA 1993; 269:753-760.

\section{APPENDIX A}

\section{Classification of Complications by Outcome}

\section{Minor Complications}

A. No therapy, no consequence.

B. Nominal therapy, no consequence; includes overnight admission for observation only.

\section{Major Complications}

C. Require therapy, minor hospitalization ( $<48$ hours).

D. Require major therapy, unplanned increase in level of care, prolonged hospitalization ( $>48$ hours).

E. Permanent adverse sequelae.

F. Death.

\section{APPENDIX B}

\section{Methodology}

Technical documents specifying the exact consensus and literature review methodologies are available upon request from the Society of Interventional Radiology, 10201 Lee Highway Suite 500, Fairfax, VA 22030.

Reported complication-specific rates in some cases reflect the aggregate of major and minor complications. Thresholds are derived from critical evaluation of the literature, evaluation of empirical data from standards of practice committee member practices, and, when available, the HI-IQ ${ }^{\circledR}$ system national database.

Consensus on statements in this document was obtained utilizing a modified Delphi technique $(60,61)$.

\section{ADDENDUM}

Dr. Curtis A. Lewis, Chairman of the Standards of Practice Committee, authored the first draft of this document and served as topic leader during the subsequent revisions of the first draft. Dr. Curtis W. Bakal is Councilor of the Standards of Practice Committee. All other authors are listed alphabetically. Other members of the Standards of Practice Committee and SIR who participated in the development of this clinical practice guideline are: Timothy Allen, MD, John Aruny, MD, Raymond Bertino, MD, Dana Burke, MD, John Cardella, MD, Paramjit Chopra, MD, Steven Citron, MD, Patricia Cole, MD, $\mathrm{PhD}$, Philip Cook, MD, Martin Crain, MD, Donald Denny, MD, Alain Drooz, MD, Elizabeth Drucker, MD, JD, Neil Freeman, MD, Gregg Gaylord, MD, Patricia Thorpe, MD, Murray Gordon, MD, Ziv Haskal, MD, James Husted, MD, Patrick Malloy, MD, Louis Martin, MD, M. Victoria Marx, MD, Terence Matalon, MD, Timothy McCowan, MD, Steven Meranze, MD, Van Moore, MD, Calvin Neithamer, MD, Albert Nemcek, Jr, MD, Steven Oglevie, MD, Kenneth Rholl, MD, Anne Roberts, MD, David Sacks, MD, Orestes Sanchez, MD, James Spies, MD, Richard Towbin, MD, Daniel Wunder, MD, Anthony Venbrux, MD, and Robert Vogelzang, MD. 
The clinical practice guidelines of the Society of Interventional Radiology attempt to define practice principles that generally should assist in producing high-quality medical care. These guidelines are voluntary and are not rules. A physician may deviate from these guidelines, as necessitated by the individual patient and available resources. These practice guidelines should not be deemed inclusive of all proper methods of care or exclusive of other methods of care that are reasonably directed toward the same result. Other sources of information may be used in conjunction with these principles to produce a process leading to high-quality medical care. The ultimate judgment regarding the conduct of any specific procedure or course of management must be made by the physician, who should consider all circumstances relevant to the individual clinical situation. Adherence to the SIR Quality Improvement Program will not assure a successful outcome in every situation. It is prudent to document the rationale for any deviation from the suggested practice guidelines in the department policies and procedure manual or in the patient's medical record. 